\title{
Dramas da Escravatura e o exotismo do comércio negreiro, do indigenato e do darwinismo social na obra de Emilio Salgari (Parte 1)
}

\begin{abstract}
Alberto Oliveira Pinto ${ }^{1}$
RESUMO: Publicado em 1896, Dramas da Escravatura é o único romance de Emílio Salgari que versa sobre a África Subsahariana não islâmica. Pretendemos analisar algumas representações do imaginário de Emílio Salgari: a abolição do tráfico de escravos e da escravatura e a correspectiva passagem do escravo a "indígena"; a racialização das culturas ou o determinismo racial como legitimador de um colonialismo de exploração; a persistente visão dicotómica acerca do homem africano enquanto "Mau Selvagem" ou "Bom Selvagem"; e finalmente o mito do "hibridismo" ou da mestiçagem.
\end{abstract}

Abstract: Published in 1896, Dramas of Slavery is the only novel by Emilio Salgari about a not Islamic Sub-Saharan Africa. We aim to analyze some of the representations of Emilio Salgari's imaginary: the abolishment of trade of slaves and slavery and the consequent passage of the slave to the condition of "indigene"; the racialization of cultures or racial determinism as a legitimator of the exploiting colonialism; the persistent dichotomic vision about the African man as a "Good Wild Man" or as a "Bad Wild Man"; and finally the myth of "hybridity" or mestizage.

PALAVRAS-CHAVE: Loango, exotismo, tráfico de escravos, abolicionismo, indigenato, darwinismo social, hibridismo, cultura, raça, eugenização da áfrica.

KEYWORDS: Loango; Exoticism; Trade of Slaves; Abolitionism; Indigenism; Social Darwinism; Hybridity; Culture; Race; Eugenization of Africa.

\footnotetext{
${ }^{1}$ Mestre e Doutorando em História de África da Faculdade de Letras da Universidade de Lisboa (FLUL).
} 


\section{Introdução}

$\mathrm{Na}$ vasta obra de romances exóticos de aventuras de Emílio Salgari (Verona, 1863-Turim, 1911), muitos dos quais com acção a decorrer no século XIX, conhecemos apenas quatro onde a temática incide sobre o espaço africano subsahariano: La favorita del Mahdi (1887), I drammi della schiavitù (1896), La Aventure di Simond Wander (?) e Lo Schiavo del Madagáscar (?). Os dois últimos romances citados, La Aventure di Simond Wander e Lo Schiavo del Madagáscar, um versando sobre as aventuras de um jovem inglês em vários pontos do mundo, nomeadamente no Congo esclavagista, o outro sobre o tráfico de escravos islâmico perpetrado entre a ilha de Madagáscar e a costa moçambicana, incluem-se entre as obras apócrifas ou "falsas" de Emílio Salgari, uma vez que, de par com muitos outros livros póstumos que lhe foram atribuídos, são na realidade da autoria do seu filho Luigi Omar Salgari (1900-1963) e de Luigi Motta (Verona, 1881 - Milão, 1955), este último vindo a distinguir-se como um dos mais famosos escritores da propaganda colonial fascista italiana. La favorita del Mahdi, publicado em Portugal pelas edições Romano Torres no início do século XX em três volumes (A Favorita do Mahdi, A Insurreição do Sudão e A Vitória do Mahdi), retrata uma África subsahariana muçulmana, no contexto da sublevação sudanesa de 1883/85, sob o comando do chefe políticoreligioso Muhammad Ahmad (1844-1885), auto-proclamado El Mahdi em 1881, contra o domínio turco dos otomanos egípcios. Sobre a África não islamizada e enquanto continente fornecedor de mão-de-obra escrava para o tráfico atlântico luso-brasileiro resta-nos, portanto, I drammi della schiavitù, publicado na Itália em 1896. Escolhemo-lo, pois, por esse motivo, para objecto deste estudo.

Pretendemos, numa apreciação deste romance - que, à semelhança da maioria dos livros de Emílio Salgari, foi publicado em edição portuguesa pela Romano Torres durante as duas primeiras décadas do século XX com o título Dramas da Escravatura -, analisar 
algumas representações do imaginário de Emílio Salgari, que se prendem com o panorama científico e político do século XIX e do início do século XX e se repercutiriam na literatura colonial portuguesa e nas próprias literaturas brasileira e angolana: a abolição do tráfico de escravos e da escravatura e a correspectiva passagem do escravo a "indígena"; a racialização das culturas ou o determinismo racial como legitimador de um colonialismo de exploração; a persistente visão dicotómica acerca do homem africano enquanto "Mau Selvagem" ou "Bom Selvagem"; e finalmente o mito luso-brasileiro do "hibridismo" ou da mestiçagem, sobretudo em relação ao sexo feminino, que influenciaria construções teóricas coloniais e pós-coloniais cujos pontos culminantes viriam a ser, num caso o lusotropicalismo de Gilberto Freyre e no outro as doutrinas da "crioulidade".

\section{O capitão Alves ou a resistência portuguesa e brasileira à abolição do tráfico de escravos e a súbita (falsa) passagem do escravo a indigena}

Escrito e publicado em 1896, cerca de dez anos depois da Conferência de Berlim (1884/85) e da consagração pelo direito internacional dos princípios da ocupação efectiva dos territórios e da condenação do tráfico de escravos e da escravatura - este último remontando já ao Congresso de Viena (1814/15) —, Dramas da Escravatura é um romance que reflecte a solidarização do autor com a preocupação européia generalizada de então na partilha da África e na sua legitimação ideológica. Neste contexto, os europeus inventam o argumento da propensão atávica dos africanos para o tráfico de escravos e da escravatura, procedendo no discurso colonial a uma curiosa operação de inversão retórica que transforma estas realidades, outrora consideradas meritórias por subtraírem os africanos à "selvajaria", em elementos de enselvajamento. Ao mesmo tempo, ao abrigo do princípio da ocupação efectiva, que legitima juridicamente a soberania das potências européias sobre territórios africanos com base 
na ocupação militar ou na celebração de tratados de protectorado com as autoridades políticas locais, os países europeus vão celebrando entre si tratados destinados a definir a régua e esquadro as fronteiras coloniais africanas. Este processo revelou-se tanto mais célere quanto mais os territórios africanos se aproximavam do litoral e tanto mais moroso quanto mais dele eles se afastavam. No caso das colónias portuguesas de Angola e Moçambique, por exemplo, se as fronteiras setentrionais e meridionais ficaram delineadas logo nos anos que se seguiram à Conferência de Berlim mediante tratados celebrados entre Portugal, Bélgica, França e Alemanha, as orientais e ocidentais mantiveram-se indefinidas por um período que se prolongaria até às vésperas da Grande Guerra de 1914/18, o que aliás estaria na origem da famosa disputa entre Portugal e a Grã-Bretanha pelos territórios centrais das Rodésias, que a historiografia portuguesa celebraria através do mito do Mapa Cor-de-Rosa.

É a esta realidade e à argumentação colonial do combate ao esclavagismo como legitimação da ocupação efectiva da África, após a independência das colónias americanas, que Emílio Salgari, em 1896, se refere ao escrever:

A proclamação da liberdade dos negros no Brasil, o último país onde subsistia a escravidão, desferiu o golpe de morte sobre os navios negreiros; mas a escravatura mantém-se ainda na África e durará até que as nações européias tenham conquistado as nações do centro (SALGARI, 1981, p.35).

Assim se compreende como é que Emílio Salgari, contrariamente ao que sucede em outras obras suas nas quais, ao encontro da idéia orientalista romântica da regeneração da Europa pela Ásia (SAID, 2001, p.124), dá vida a heróis asiáticos que combatem a dominação colonial, de que o exemplo mais conhecido é o pirata Sandokan, príncipe malaio destronado pelo colonialismo britânico - ainda que também aí se mostre simpatizante de uma solução eugenística, pois Sandokan elege como rainha dos seus domínios Mariana Guillonk, filha de pai inglês e de mãe italiana -, no que diz respeito à África e aos africanos não hesita em 
enveredar por um discurso apologético da colonização branca e enselvajador das populações negras.

A acção de Dramas da Escravatura decorre no ano de 1858, no litoral do Loango, num porto de embarque clandestino de escravos situado na chamada Baía de Lopes, evocativa do nome do embaixador português Duarte Lopes, que entre 1578 e 1588 residiu em Mbanza Kongo, na corte do Rei do Kongo, sendo depois por este enviado ao Papa Sixto V e fornecendo em Roma ao cronista Filippo Pigafetta as notas do relato publicado em 1591 que ficaria conhecido por Relação do Reino do Congo e das Terras Circunvizinhas (PIGAFETTA e LOPES, 1989). O Reino do Loango, organização política africana outrora dependente do Reino do Kongo, ficaria na posse dos franceses depois da divisão das fronteiras coloniais operada em consequência da Conferência de Berlim, e o seu território - exceptuando as matas do Mayombe, que passaram a fazer parte do enclave de Cabinda, de administração portuguesa até à independência de Angola em 1975 e angolana após esta data integraria o actual Congo-Brazaville (PINTO, 2006, p.255-260).

Compreender a teia em que se envolvem as personagens de Emílio Salgari neste romance de acção, dividido por vinte e quatro movimentados capítulos, implica o conhecimento de factos históricos do século XIX anteriores a 1858. Salgari preenche todo o Capítulo IV, intitulado precisamente "O tráfico dos negros", com uma resenha um tanto redundante, incompleta e imprecisa acerca do tráfico de escravos e da escravatura, realidades que não consegue distinguir com clareza uma da outra, preocupado apenas em exaltar os aspectos dramáticos de ambas e limitando-se a atribuir o êxito do abolicionismo exclusivamente a factores de ordem filosófica e humanitária, através de uma referência aos Iluministas do século XVIII. Ignora completamente o peso que a independência dos EUA e a revolução industrial tiveram para que o abolicionismo viesse a ser consagrado no Congresso de Viena (1814-1815) e conseqüentemente imposto pela Grã-Bretanha país agora privado das suas colónias americanas mas dispondo de uma economia suficientemente industrializada para abdicar da mão-de-obra 
escrava em favor da exploração do "trabalho livre" - aos seus parceiros económicos internacionais, o que viria a apressar a supressão do tráfico de escravos - e só mais tarde da escravatura - na Dinamarca (1792), na própria Grã-Bretanha (1806), na Suécia (1813), na Holanda (1814), na França (1815) e na Espanha (1817). Indica, contudo, acertadamente que Portugal foi o primeiro país europeu a desenvolver o tráfico da escravatura negra destinada à Europa e ao continente americano e o último a aboli-lo juridicamente, assim como à própria escravatura, persistindo na sua prática clandestina até um período muito tardio do século XIX que atingiu em alguns casos os primeiros anos do século XX. Neste ponto não podia deixar de suscitar a indignação do tradutor português, que à semelhança da maioria dos seus compatriotas muitos dos quais infelizmente ainda nossos contemporâneos -, procede em duas notas de rodapé à operação retórica de ocultação e negação do passado esclavagista de Portugal com argumentos farisaicos e falaciosos tais como o de que em data anterior ao "descobrimento" da África pelos portugueses (pasme-se!), já os outros europeus traficavam escravos brancos, além da evocação da malograda legislação de Sá da Bandeira e de uma alusão deslocada e despropositada à liberdade dos índios do Brasil artificialmente apregoada pelo padre António Vieira (SALGARI, 1981, p. 30-53, notas de rodapé da p. 30 e da p.34).

À resistência portuguesa e brasileira à abolição do tráfico de escravos e da escravatura e à sobrevivência, após a independência do Brasil em 1822, da legalidade do tráfico negreiro português no hemisfério sul entre a costa angolana e o litoral brasileiro, devido em grande medida à habilidade diplomática do duque de Palmela, viria a pôr travão a aprovação em 1839 do bill de Palmerston pelo parlamento britânico, que permitiu aos navios ingleses fiscalizar os cargueiros portugueses e brasileiros a sul do Equador e declará-los piratas caso se descobrissem escravos a bordo, o que precipitou a celebração de um tratado abolicionista entre Portugal e a Grã-Bretanha em 1842 que só viria a ser ratificado, isto é, a entrar em vigor entre as partes, cinco anos depois. Daqui decorreu, não apenas a instalação por parte da Grã- 
Bretanha de consulados em São Tomé, Luanda e Lourenço Marques, cujos pontos estratégicos das suas localizações nestas cidades permitiam aos ingleses vigiar o embarque de navios negreiros, mas também o patrulhamento das costas africanas por navios militares britânicos destinados a vigiar o tráfico clandestino. Tais patrulhas navais, designadas em Portugal, Angola e Brasil por "cruzeiros", conforme muito acertadamente o escreve Salgari - "Os Cruzeiros", aliás, é o título do Capítulo II -, operavam, no caso angolano, sobretudo no litoral a norte do Ambriz, região sobre a qual os portugueses, que haviam tomado violentamente esta localidade africana em 1855, não exerceram qualquer soberania antes de 1887, não obstante os governadores coloniais incitarem a partir de Luanda os comerciantes de escravos a embarcar a sua mercadoria em pontos recônditos da costa, nomeadamente nos portos então independentes de Cabinda (Ngoio e Kakongo) e Loango. O tráfico clandestino fora de Luanda e de Benguela viria a crescer ainda mais quando, depois de a legislação do senador brasileiro Euzébio Queiroz em 1850 proibir o desembarque de escravos em portos do Brasil, se assiste a um aumento considerável dos impostos alfandegários naquelas duas principais cidades angolanas (PINTO, 2006, p.213-219 e p.236-244).

É neste contexto que em 1858 o "Guadiana", navio brasileiro hasteando bandeira portuguesa - decerto para salvaguardar a sua protecção pelo governador de Angola -, comandado pelo capitão Alves, aporta na Baía do Lopes com o fim de adquirir do rei Bango, chefe africano local, a troco de garrafas de rum ordinário e de aguardente sem dúvida a gerebita, a cachaça brasileira, principal moeda mercadoria dos negreiros nesta região -, espingardas, velhas facas, fardas de militares já usadas, missangas, panos e peças de algodão, cerca de seiscentos cativos destinados a embarcar para o Brasil. O capitão Alves, descrito por Emílio Salgari como um homem que "devia contar trinta a trinta e cinco anos", "de estatura elevada, formas vigorosas, embora elegantes, pele amorenada e com olhos de um negro brilhante que muitas mulheres invejariam" e cuja "barba negra, cortada 
à americana, lhe adornava o rosto, notando-se ao primeiro golpe de vista que devia ser dotado de coragem pouco vulgar e de audácia a toda a prova", é um brasileiro de origem portuguesa reputado enquanto "um dos mais audaciosos negreiros que por esse tempo sulcavam o Atlântico", que "sabia defrontar os cruzeiros escalonados nas costas africanas para impedir o tráfico da escravatura", que "fizera já trinta viagens da costa de África ao Brasil, sempre com carregamento de escravos" e que "embora dispusesse de importante fortuna, não pensava em retirar-se do arriscado modo de vida que adoptara” (SALGARI, 1981, p.17-18). Para evitar a triste sorte que coubera a seu pai, capturado por dois "cruzeiros" ingleses doze anos antes e vergonhosamente enforcado, Alves concebera e mandara construir nos estaleiros de Glascow um veleiro com mastreação mais do que a necessária, a fim de facilmente poder escapar às perseguições dos navios britânicos. Esse veleiro, o "Guadiana”, cuja tripulação era composta de cerca de quarenta homens oriundos de todos os pontos da América e da Europa, viajava armado e era o maior dos navios negreiros daquela época, pois além de ter 1200 toneladas de arqueação, dispunha de um porão espaçoso capaz de comportar cerca de 800 escravos (SALGARI, 1981, p.43).

Mas Alves, acometido de súbita paixão por Seghira, uma escrava mulata, decide renunciar ao que classifica como "infame tráfico" e propõe-se, caso consiga regressar ao Brasil, retirar-se para a Baía ou para o Rio de Janeiro, comprar uma fazenda, tornar-se plantador e ficar com todos os escravos que carrega a bordo do "Guadiana", para os quais será, declara, "mais um amigo do que um senhor" (SALGARI, 1981, p. 77-78). Embora de momento renunciemos à tentação de ver neste "arrependimento" de um negreiro motivado pelo amor por uma mestiça uma antecipação, por parte de Emílio Salgari, de um certo mulatismo literário próprio do lusotropicalismo freyreano, não podemos deixar de reconhecer que o capitão Alves, propondo-se ingressar na galeria dos "patrões bons" - mito que as personagens de Uncle Tom's Cabin (A Cabana do Pai Tomás), o famoso romance da norte-americana Harriet Beecher Stowe publicado em 1852, contribuiriam de forma 
única para celebrizar —, personifica em grande medida o percurso das sociedades portuguesa e brasileira ao longo da segunda metade do século XIX e início do século $\mathrm{XX}$ no que diz respeito ao seu posicionamento perante o tráfico de escravos e a escravatura: a uma fase de resistência e prevaricação em relação às normas de direito internacional sucede-se uma outra de reformas legislativas apressadas, que em Portugal tem início em 1875 com o primeiro Código de Trabalho Indigena, destinada a criar a máscara jurídica que transforma o antigo escravo em "homem livre" cuja inferioridade e selvajaria congénitas, aferidas biologicamente pelo tamanho do crânio e pela cor da pele, justificam que continue sujeito à disciplina de trabalho imposta pelo homem branco, o qual vai doravante proclamar-se um "amigo" do negro.

Esta operação - que no caso das colónias portuguesas no continente africano poderíamos designar, com Isabel Castro Henriques, por "(falsa) passagem do escravo a indígena” (HENRIQUES, 2004) e no caso brasileiro pela expressão "colonialismo interno" introduzida por Walter D. Mignolo (MIGNOLO, 2003) - é manifestamente preconizada neste romance por Emílio Salgari, se bem que o capitão Alves mais não seja do que um simples prenúncio, uma vez que esta personagem tem a infelicidade de morrer a bordo do "Guadiana", cobardemente assassinado pelo bretão Kardec, o seu sinistro imediato que, igualmente apaixonado até à loucura pela mulata Seghira, alveja inicialmente o rival com um tiro de pistola desfechado pelas costas durante um combate naval com um cruzeiro britânico, pondo-lhe depois definitivamente fim à vida com uma punhalada no peito quando, aproveitando a confusão de um abalroamento, entra furtivamente no quarto onde Alves convalesce do ferimento causado pela bala (SALGARI, 1981, p. 55-63 e p.105-113). É este, pois, o primeiro "drama da escravatura”, que faz jus ao título da obra: o do negreiro arrependido incapacitado de levar a cabo os seus bons intentos em relação aos antigos escravos devido à acção homicida e malfazeja de outro branco 
que, além de (e quiçá por) não ser de origem portuguesa, é retrógrado, cruel e recalcitrante.

\section{O doutor Estêvão ou a perspectiva salgariana sobre o determinismo racial e o darwinismo social como fundamentos do colonialismo}

Como vai Emílio Salgari manifestar a sua adesão às teses que, apregoando o abolicionismo, mais não pretendiam senão legitimar a transformação aparente do homem africano de escravo em indígena, destinado a continuar a servir de mão-de-obra nas unidades de produção dos continentes americano e africano no âmbito de uma nova concepção de economia industrializada que visava o escoamento dos produtos para o mercado mundial? Através de uma outra personagem luso-brasileira, o doutor Estêvão. Médico de bordo do "Guadiana" e ao cabo de uma vida a navegar em navios negreiros, havendo sido grande amigo do pai de Alves do mesmo modo que o era do filho, o velho Estêvão declara-se surpreendentemente... abolicionista! Como sustenta ele os seus pontos de vista? Aderindo ao transformismo lamarckiano e ao darwinismo social, isto é, às doutrinas que procuraram aplicar à sociedade os princípios científicos da mutabilidade das espécies e da selecção natural, estabelecidos por Charles Darwin (1809-1882).

No Capítulo XII (SALGARI, 1981, p.85-90), a prelecção a que o doutor Estêvão submete o capitão Alves e o contramestre Furtado resume todo o processo de hierarquização das culturas através da sua classificação em "raças", operado nos meios científicos europeus ao longo de todo o século XIX. O então aceso debate entre as perspectivas poligenistas, que viam a humanidade constituída por diversas espécies com diferentes origens, e as monogenistas, que de acordo com a Bíblia sustentavam que os homens provinham todos do mesmo ramo, é levantado pelo contramestre Furtado, ao duvidar do argumento, que cientificamente inspiraria o mito "Hamita" ou "Camita", segundo o qual a "raça negra" proviria da "branca" por descender de Cham, um dos filhos de Noé. Furtado está mesmo convicto, aliás em consonância com 
uma concepção já vinda da Idade Média (PARREIRA, 1998, p.31-32), de que "os negros descendem do demónio" (Sic.). O doutor Estêvão, por sua vez, afirma-se desde logo um monogenista e um partidário das teorias de Lamarck, o qual, sublinha, "encontra um formidável defensor no ilustre Darwin” (Sic.) (SALGARI, 1981, p. 87-88).

A este respeito registe-se o anacronismo em que incorre Emílio Salgari, na medida em que é impossivel que o doutor Estêvão tenha lido o ensaio On the origin of species by means of natural selection, or the preservation of favoured races in the strugle for life de Charles Darwin que revolucionaria a biologia e a antropologia de então e onde, efectivamente, era recuperado o principio transformista da hereditariedade dos caracteres adquiridos, enunciado por Lamarck em 1808 -, pois esta obra só seria publicada em 1859, ou seja, um ano depois daquele em que decorre a acção de Dramas da Escravatura, do mesmo modo que é improvável que este médico de bordo brasileiro tenha tido acesso aos esparsos trabalhos publicados anteriormente pelo naturalista britânico. Acresce ainda que, conforme o parece indicar o ostracismo a que foram votados os naturalistas que ousaram preconizar propostas transformistas antes de 1859 - de entre os quais se destacam, além do já mencionado Jean-Baptiste de Lamarck (17441829), o seu compatriota Étienne Geoffroy Saint-Hilaire (1772-1844) e os britânicos Robert Chambers (1802-1871) e Erasmus Darwin (17311802), este último avô paterno de Charles Darwin - até esse ano da chamada "revolução darwiniana" a doutrina firme e incontestavelmente instalada nos meios científicos era a da criação das espécies e da constância e imutabilidade das mesmas, cuja grande autoridade de referência era Georges Cuvier (1769-1832) (PEREIRA, 2001, p. 21-46), a qual inspirava construções teóricas tendencialmente poligenistas que identificavam a noção de "espécie" com a de "raça" e, consequentemente, consideravam que um ser humano gerado por dois indivíduos de "raças" ou "espécies" humanas diferentes - o "híbrido" ou o "mulato", na expressão portuguesa zoomórfica - seria um ser infértil ou condenado a sê-lo após a degradação sofrida ao fim de 
algumas gerações, sobretudo ao nível da inteligência e das aptidões para um desenvolvimento cultural e civilizacional (YOUNG, 1995, p. 628). Com muito maior probabilidade o doutor Estêvão perfilharia esta orientação pré-darwiniana, particularmente na vertente que Robert Young designa por versão negativa ou pessimista da tese da "amalgamação" das espécies - defendida, entre outros, por Louis Agassiz (1808-1873), ao tempo já com enorme popularidade no Brasil, e por Joseph Arthur de Gobineau (1816-1882) no seu então recente Essai sur l'inégalité des races humaines, publicado em quatro volumes entre 1853 e 1855 -, que sustentava que a miscigenação produzia grupos "mistos" degenerados e degradados, conduzindo ao "caos das raças" (YOUNG, 1995, p.101-109).

Mas se o doutor Estêvão não podia ser um darwinista em 1858, Emílio Salgari seguramente o era em 1896, razão pela qual coloca anacronicamente na boca desta personagem de Dramas da Escravatura um discurso que reproduz a teoria monogenista e evolucionista da descendência com modificações, elaborada por um dos mais fervorosos seguidores de Darwin, o zoólogo alemão Ernst Haeckel (1834-1919). Na sua História da Criação (1867), Haeckel ilustra a sua teoria com uma árvore genealógica do homem que seria mais tarde reproduzida, quer pelo próprio Darwin em 1871 no seu The Descent of Man and Selection in Relation to Sex, quer por variadíssimos autores, entre os quais, já em 1880, o historiador e antropólogo português Joaquim Pedro de Oliveira Martins (1845-1894) (PEREIRA, 2001, p. 50-57 e p.229-284). Considerando que os homens, classificados zoologicamente como uma família na ordem dos primatas e na classe dos mamíferos, provêm todos de uma origem comum - remontando a ramificações do grupo dos macacos outrora extintas e transformadas por acção do mecanismo darwiniano da selecção natural que assegurava a descendência com modificações - e introduzindo a figura do pitecantropo álalo, privado do uso da fala, como um estádio intermédio que separa o homem do antropóide, Haeckel concebia as espécies apenas enquanto momentos passageiros de individualização das características humanas num 
processo evolutivo e não já como tipos absolutos e imutavelmente constantes à maneira dos poligenistas. Cada uma dessas espécies, evoluindo isoladamente consoante a sua dispersão e correspondendo a um grupo linguístico irredutível com um determinado tipo de cabelo transmitido pela genealogia - e não necessariamente uma determinada medida do crânio -, constituiria uma das doze "raças humanas" conhecidas, por sua vez divididas em 36 sub-raças. As doze "raças humanas" figuram na árvore genealógica de Haeckel apresentadas hierarquicamente desde a base até ao topo, como se umas fossem a evolução das outras. Entre as quatro "raças" da base que se seguem imediatamente ao pitecantropo álalo encontram-se, além da Papua da Oceânia, com o número I, três "raças" africanas: a Hotentote, a Cafre e a Negra, respectivamente com os números II, III e IV. Curiosamente muito mais acima, já com os números X e XI, estão duas "raças" igualmente africanas, a Drávida e a Núbia, consideradas por Haeckel mais "evoluídas" do que a Austrália (V), a Malaia (VI), a Mongólica (VII), a Árctica (VIII) e a Americana (IX). A hierarquia é encimada com a "raça" número XII, a Mediterrânica, dentro da qual o sub-grupo basco ou semita fica a perder consideravelmente em "evolução" se comparado com o outro sub-grupo da mesma "raça", o caucasiano ou ariano (OLIVEIRA MARTINS, 1987, p.147-153).

A partir da classificação de Haeckel e evocando igualmente os critérios classificatórios linguísticos utilizados pelos orientalistas Ernest Renan (1823-1892) e Max Müller (1820-1900), Oliveira Martins elabora - na mesma obra onde afirma que "civilizar" os negros é como "dar a crianças de peito o alimento próprio dos adultos”(Sic.), ao mesmo tempo que, ao encontro da proposta eugenista de Gobineau em relação ao Brasil, preconiza para a África uma imigração maciça de europeus dois esquemas que designa, de acordo com uma concepção que fundia no mesmo significado os neologismos "etnia" e "raça", um por etnogeográfico e o outro por etnogénico, nos quais hierarquiza as "raças" dos povos africanos classificando-as como "indígenas" (OLIVEIRA MARTINS, 1978, p.242-257). Influenciando sobremaneira o seu 
compatriota e discípulo Francisco António Pinto, cujo pensamento a respeito de Cabinda analisámos noutro lugar (PINTO, 2006, p. 113125), Oliveira Martins começa por dividir a África Centro-Austral (ou Subsahariana) em três regiões: a Nigrícia, a Hotentótia e a Cafraria. Na primeira distingue a "raça" negro-berbere, que considera "mestiça" e onde inclui os fulos e os mandingas da Guiné, da negra, que subdivide em congos, abrangendo todos os povos de Angola excepto os lundas, e em cafres, que abaixo arrumará na terceira região, que estende desde o planalto da Lunda - integrando, pois, os seus naturais, os lundas para todo o sudeste do continente. Quanto à segunda região, a Hotentótia, parece dispersa por várias bolsas, conforme as migrações dos povos que lhe dão nome, os koi-san, que os holandeses designaram por hotentotes ou huttenhute, literalmente os gagos ou "os que falam aos soluços” (M'BOKOLO, 2003, p. 494). Como hierarquiza o autor estas "raças"? À maneira de Haeckel, aferindo o seu grau de evolução cultural pelas línguas faladas, pela textura do cabelo (os eriócomos, de cabelo "encarapinhado", os lofócomos, de cabelo "espetado" e os euplócomos, de cabelo encaracolado, embora fino) e ainda, senão pela medida dos crânios, pela dos queixos (os prognatas, de queixo inferior alongado para a frente, e os ortognatas, de maxilares equilibrados) e pela das nádegas femininas. Os povos africanos são, pois, para Oliveira Martins, tanto mais evoluídos quanto mais os seus idiomas se aproximem dos chamados idiomas caucasianos, quanto menos espessos forem os seus cabelos, quanto mais reduzidos forem os seus queixos e... quanto menos esteatopígicas forem as suas mulheres! Assim sendo, na base da pirâmide do seu esquema etnogénico coloca dois ramos da "raça hotentote”, os bosquímanos e os cafro-hotentotes, aos quais sobrepõe os já aludidos congos e cafres, a que se seguem os guinéus e os nilotas, chamados negróides propriamente ditos. Mas observe-se que, acima dos negróides, Oliveira Martins traça uma linha que designa por "zona de cruzamentos" e da qual provêm as "raças" misturadas ou embranquecidas que se encontram no topo da pirâmide, os fulos do Sudão e - ainda mais "lissótricos" e "euplócomos" ou de cabelo mais 
liso do que estes e por isso mais "avançados" — os núbios da região nilótica (OLIVEIRA MARTINS, 1978, p.250-252).

Voltemos agora ao doutor Estêvão e verifiquemos que esta personagem de Emílio Salgari, além de classificar a chamada "raça negra" como uma família dividida em vários grupos, cada um dos quais apresentando caracteres diversos, hierarquiza-os segundo o mesmíssimo critério utilizado por Oliveira Martins, que o escritor italiano decerto aprendeu lendo Max Müller ou o próprio Haeckel. O primeiro "grupo" a que alude o doutor Estêvão é o dos bosquímanos ou bosjemanos, "a raça mais antiga e mais próxima do tipo original”, os quais, do seu ponto de vista, são negros que "vivem nas regiões interiores do Cabo da Boa Esperança e estendem-se até ao Zambeze”, "não têm a pele inteiramente negra, mas cor de cacau, amarelada e, embora os cabelos sejam encarapinhados, não formam emaranhados anéis", "são de estatura baixa” e "são nómadas e vivem da caça”. O segundo "grupo" é o dos hotentotes, que “ocupam a África meridional” e "têm a pele cor de sola velha e a estatura superior à dos anteriores, chegando, geralmente, a um metro e cinquenta centímetros", diferenciando-se dos bosquimanos ainda pelo facto de serem pastores. Prossegue o médico negreiro e abolicionista, na sua hierarquização dos "grupos" africanos, afirmando que aquele "grupo" que se encontra logo acima dos dois primeiros é "o dos verdadeiros negros", que "têm as pernas um pouco arqueadas, pés espalmados, nariz achatado, lábios muito grossos e o cabelo curto e lanoso", sendo também os mais indicados para o trabalho de escravo - ou de "indígena"! —, uma vez que "são os que melhor suportam todas as fadigas e ocupam grande parte do continente africano, sobretudo as regiões centrais”. O quarto patamar da pirâmide do doutor Estêvão - ou de Emílio Salgari - é ocupado pelos cafres, que "formam outro grupo, o de tipo mais formoso", sendo um povo que, "espalhado pela costa oriental da África meridional, é altivo e belicoso", cujos “exemplares” são “altíssimos, pois, geralmente, excedem um metro e sessenta centímetros, dispõem de belas proporções e são esbeltos e elegantes nos movimentos". E 
finalmente, ocupando o vértice da pirâmide no grau mais elevado da escala, temos os "mais embranquecidos", isto é, o "grupo" núbio, "que vive na África setentrional e compõe um povo de conquistadores" (SALGARI, 1981, p.86-87).

Não é, pois, de admirar que o darwinismo social de Salgari, expresso através do discurso do doutor Estêvão, se apresente igualmente na sua dimensão eugenística, isto é, de "limpeza" ou de "aperfeiçoamento" da "raça". Se os defensores da "teoria dos tipos humanos" anteriores a Darwin, na maioria poligenistas, já se mostravam abertos a hipóteses de "hibridismo" ou mestiçagem no sentido da criação de um "terceiro tipo", a tendência de quase todos era para encararem a "amalgamação" das espécies na sua versão negativa e pessimista do "caos das raças", ainda que alguns deles, como o próprio Gobineau quanto ao Brasil, já apresentassem em relação a certos casos propostas eugenistas. O darwinismo social, porém, embora continuasse a ver as relações entre povos de "raças" diferentes como um facto biologicamente determinado, assumiu quanto a esta questão da "amalgamação" uma perspectiva positiva e optimista, na medida em que os seus seguidores acreditaram que a operação de selecção natural criaria "raças puras" a partir da mistura de "raças" diversas. As concepções eugenistas - expressão introduzida, a partir dos vocábulos latinos eu (boa) e genus (geração), por Francis Galton (1822-1911), primo direito de Charles Darwin que nele se inspiraria para, na sua obra Inquires to Human Faculty, publicada em 1883, sugerir a proibição de casamentos inter-raciais a fim de combater a proliferação das consideradas "raças inferiores" - encontraram, pois, uma legitimação científica mais sólida e, consequentemente, multiplicaram-se. Tal foi o caso, como vimos, da posição teórica assumida por Oliveira Martins, quer ao defender uma imigração maciça de brancos para o continente africano, quer ao considerar os fulos e os núbios, que no seu esquema etnogénico da África coloca acima da linha da "zona de cruzamentos", mais evoluídos do que os demais povos negros por se tratar de "raças misturadas", com caracteres físicos da "raça branca". É essa a 
perspectiva que Salgari perfilha ao colocar na boca do doutor Estêvão a seguinte exclamação: "Tem-se observado que certas raças melhoram, notavelmente, pelos cruzamentos, e que o ambiente e as necessidades da vida desenvolvem nelas faculdades de que antes careciam!" ( SALGARI, 1981, p.89).

À semelhança de muitos autores seus contemporâneos e de tantos que o seguiram, Emílio Salgari apresenta na sua literatura exótica duas das mais relevantes linhas mestras por que se regeu a ideologia colonial, concretamente a portuguesa, no que diz respeito à perspectivação do homem africano por parte do europeu: para que o africano, "raça" pueril e atrasada mas fisicamente vigorosa, assimile a lição "civilizadora" do homem branco, deve submeter-se-lhe através do indigenato, que substitui a escravatura - não se misturando com ele, de acordo com a perspectiva pessimista galtoniana do darwinismo social -, ou, em alternativa, deve tornar-se objecto de uma operação sexual do colonizador que visa, alegadamente, "aperfeiçoar-lhe" a "raça”. Falta-nos ver como é que, para sustentar esta ideologia, Emílio Salgari constrói as suas personagens africanas.

\section{Referências Bibliográficas}

Bibliografia Activa

SALGARI, Emílio. Dramas da Escravatura ${ }^{2}$, Trad. Bernardo de Alcobaça, Capa e desenhos de texto de Eugénio Silva. Lisboa: Edição Romano Torres, 6ª edição, 1981, 166 p.

Bibliografia Passiva

Obras de (ou atribuídas a) Emílio Salgari consultadas

- Sandokan o Tigre da Malásia ${ }^{3}$, Trad. Henrique Marques Júnior. Lisboa: Verbo, 2000, 201 p.

- A Favorita do Mahdi ${ }^{4}$, Trad. Henrique Marques. Lisboa: Edição Romano Torres, s.d., $152 \mathrm{p}$.

2 Título da edição original italiana de 1896: I Drammi della Schiavitú.

3 Título da edição original italiana de 1900 (ou de 1894?): Le Tigri di Mompracem.

4 Título da edição original italiana de 1887, que abrange os dois volumes subsequentes: La favorita del Mahdi. 
- A Insurreição do Sudão, Trad. Henrique Marques. Lisboa: Edição Romano Torres, s.d., 160 p.

- A Vitória do Mahdi, Trad. Henrique Marques. Lisboa: Edição Romano Torres, s.d., 138 p.

- As Aventuras de Simão Wander5, Trad. Carlos José de Menezes. Lisboa: Edição Romano Torres, s.d., 176 p.

- O Escravo de Madagáscar6, Trad. Henrique Marques. Lisboa: Edição Romano Torres, s.d., 144 p.

Estudos

DUARTE, Eduardo de Assis. Jorge Amado: Romance em Tempo de Utopia. Rio de Janeiro/São Paulo: Editora Record, 1996, 277 p.

HENRIQUES, Isabel Castro. A (falsa) passagem do escravo a indígena, In Os Pilares da Diferença. Relações Portugal-África Séculos XV-XX. Lisboa: Centro de História da Universidade de Lisboa, 2004, p. 285-297.

MACHADO, Pedro Félix. Cenas de África. ?. Romance íntimo, Organização e Prefácio de E. Bonavena. Lisboa: Imprensa Nacional - Casa da Moeda, 2004, $251 \mathrm{p}$.

MARGARIDO, Alfredo. A Lusofonia e os Lusófonos: Novos Mitos Portugueses. Lisboa: Edições Universitárias Lusófonas, 2000, 88 p.

MARTIN, Phyllis M. The External Trade of the Loango Coast 1578-1870. The effects of changing commercial relations on the Vili Kingdom of Loango. Oxford: University Press, 1972, 193 p.

MATOS, Patrícia Ferraz de. As Cores do Império. Representações Raciais no Império Colonial Português. Lisboa: Imprensa de Ciências Sociais, 2006, $287 \mathrm{p}$.

M'BOKOLO, Elikia. África Negra. História e Civilizações. Tomo I até ao Século XVIII, Trad. Alfredo Margarido. Lisboa: Editora Vulgata, 2003, 584 p.

MIGNOLO, Walter D. Histórias Locais / Projectos Globais. Colonialidade, Saberes Subalternos e Pensamento Liminar, Trad. Solange Ribeiro de Oliveira. Belo Horizonte: Editora UFMG, 2003, 503 p.

MOURALIS, Bernard. As Contra-Literaturas, Trad. António Filipe Rodrigues Marques e João David Pinto Correia. Coimbra: Livraria Almedina, 1982, $227 \mathrm{p}$.

OLIVEIRA MARTINS, Joaquim Pedro de. O Brasil e as Colónias Portuguesas. Lisboa: Guimarães Editores, $7^{\mathrm{a}}$ edição aumentada, 1978 ( $1^{\mathrm{a}}$ edição de 1880), $268 \mathrm{p}$.

OLIVEIRA MARTINS, Joaquim Pedro de. Elementos de Antropologia (História Natural do Homem), Prefácio do Dr. José Marinho. Lisboa: Guimarães Editores, $8^{\mathrm{a}}$ edição, 1987 ( $1^{\mathrm{a}}$ edição de 1880), 222 p.

PARREIRA, Adriano. "A Máquina de Dúvidas". O Conceito de Negro na Literatura de Viagens sobre Angola. Séculos XV-XVII. Luanda: INALD, 1998, $122 \mathrm{p}$.

PEREIRA, Ana Leonor. Darwin em Portugal. Filosofia. História. Engenharia Social (1865-1914). Coimbra: Livraria Almedina, 2001, 628 p.

\footnotetext{
5 Obra apócrifa. Título da edição original italiana de data desconhecida (mas posterior a 1911, data da morte de Emílio Salgari): La Aventure di Simond Wander.

6 Obra apócrifa. Título da edição original italiana de data desconhecida (mas posterior a 1911, data da morte de Emílio Salgari): Lo Schiavo del Madagáscar.
} 
PIGAFETTA, Filippo e LOPES, Duarte. Relação do Reino do Congo e das Terras Circunvizinhas, Comentário e Transcrição em português actual de António Luís Alves Ferronha. Lisboa: Publicações Alfa, 1989, 139 p.

PINTO, Alberto Oliveira. Cabinda e as Construções da sua história. 1783-1887, Prefácio de Alfredo Margarido e Isabel Castro Henriques. Lisboa: Dinalivro, 2006, 306 p.

PINTO, Alberto Oliveira. A Oralidade no Romance Histórico Angolano Moderno. Lisboa: Novo Imbondeiro, 2003, 74 p.

PINTO, Alberto Oliveira. O Concurso de Literatura Colonial da Agência Geral das Colónias (1926-1951); Colonialismo e Propaganda, In Clio. Lisboa: Centro de História da Faculdade de Letras da Universidade de Lisboa, Nova Série, Vol. 7, 2002, p.191-256.

SAID, Edward W. Culture et Impérialisme, Trad. Paul Chemla. Paris: Fayard Le Monde Diplomatique, 2000, 558 p.

SAID, Edward W. Orientalismo. O Oriente como invenção do Ocidente, Trad. Tomás Rosa Bueno. São Paulo: Companhia das Letras, 2001, $370 \mathrm{p}$.

SERRANO, Carlos Moreira Henriques. O Poder Político no Reino Ngoyo. Um Estudo Sociológico. Dissertação de Mestrado apresentada à Faculdade de Filosofia, Letras e Ciências Humanas da Universidade de São Paulo. São Paulo: 1979, 135 p.

SPURR, David. The Rhetoric of Empire. Colonial Discurse in Journalism, Travel Writing and Imperial Administration. Durban \& London: Duke University Press, 1993, 208 p.

YOUNG, Robert J. C. Colonial Desire. Hibridity in Theory, Culture and Race. London and New York: Routledge, 1995, 236 p. 